\title{
Uptake of Succinate and Malate in Cultured Cells and Bacteroids of Two Slow-growing Species of Rhizobium
}

\author{
By MICHAEL J. D. SAN FRANCISCO† AND GARY R. JACOBSON* \\ Department of Biology, Boston University, Boston, MA 02215, USA
}

(Received 12 July 1984; revised 16 October 1984)

\begin{abstract}
The uptake of succinate and malate has been compared in cultured cells and bacteroids of two species of slow-growing Rhizobium: $R$. japonicum (USDA I-110) and cowpea Rhizobium (USDA 3278). Cultured cells of both organisms actively accumulated both compounds, and uptake was abolished by KCN and 2,4-DNP, but not by arsenate. Kinetic studies using cultured cells showed that succinate competitively inhibited malate uptake, and vice versa, implying a common step in the uptake of these dicarboxylic acids. Uptake of both of these compounds was inhibited by osmotic shock and $N$-ethylmaleimide in cultured cells of both species. Purified bacteroids accumulated succinate in a process that was sensitive to 2,4-DNP and KCN, but at a rate significantly slower than for cultured cells. No detectable malate uptake was observed in purified symbiotic cells. Furthermore, succinate uptake was insensitive to osmotic shock in bacteroids of both strains. These results show that although bacteroids of both strains are competent in succinate uptake, significant differences exist in the expression and/or stability of dicarboxylate uptake systems between free-living and symbiotic cells.
\end{abstract}

\section{INTRODUCTION}

The potential role of dicarboxylic acids in the formation of effective legume-Rhizobium symbioses has recently been the focus of much investigation (Ronson et al., 1981; Gardiol et al., 1982; Finan et al., 1983). Mutants of Rhizobium leguminosarum defective in succinate transport have been found to be defective in symbiotic nitrogen fixation (Finan et al., 1983). Succinate transport mutants of $R$. trifolii (Ronson et al., 1981) and succinate dehydrogenase mutants of $R$. meliloti (Gardiol et al., 1982) have also been found to be incapable of effective symbiotic nitrogen fixation, suggesting the importance of succinate as a source of energy and reductant in the symbiotic state. Observations that dicarboxylates may play a regulatory role by modulating the uptake of other carbon compounds have been made in several species of Rhizobium (Ucker \& Signer, 1978; Dilworth \& Glenn, 1981). Also, in free-living cells the uptake of dicarboxylates has been shown to be modulated by other carbon compounds (Glenn et al., 1980; Finan et al., 1981; McAllister \& Lepo, 1983). These observations suggest that dicarboxylic acids may play a role in the maintenance of effective legume-Rhizobium symbioses.

Most of the results summarized above were obtained in studies on fast-growing species of Rhizobium. Because slow-growing species of Rhizobium such as $R$. japonicum and cowpea rhizobia are sufficiently distinct from the fast-growers to justify their inclusion into a suggested new genus, Bradyrhizobium (Jordan, 1982), it was of interest to investigate the uptake of dicarboxylates in members of this group. Two recent reports have studied dicarboxylate uptake (i.e. transport plus metabolism) in $R$. japonicum. McAllister \& Lepo (1983) reported active uptake of succinate and malate in cultured cells of this species, while Reibach \& Streeter (1984) studied accumulation of dicarboxylates in symbiotic cells. However, extensive comparative

$†$ Present address: Department of Biological Chemistry, University of Maryland School of Medicine, Baltimore, MD 21201, USA.

Abbreviation: NEM, $N$-ethylmaleimide. 
studies on dicarboxylate uptake in these two distinct cell forms have yet to be reported. Furthermore, the bacteroid purification procedure used by Reibach \& Streeter (1984) does not separate differentiated bacteroids from partially differentiated cells ('transforming' bacteria) and untransformed bacteria (Reibach et al., 1981).

In this report, results of experiments investigating succinate and malate uptake in cultured cells, crude bacteroids and purified bacteroids of $R$. japonicum (USDA I-110) and cowpea Rhizobium (USDA 3278) are presented. These studies add further insight into the physiological changes that must occur in the bacterial cell during its differentiation into an effective, nitrogenfixing bacteroid in the legume root nodule.

\section{METHODS}

Materials. [U-14 C]Succinate $\left(1.85 \mathrm{GBq} \mathrm{mmol}{ }^{-1}\right)$ and $\left[\mathrm{U}-{ }^{14} \mathrm{C}\right] \mathrm{malate}\left(1.85 \mathrm{GBq} \mathrm{mmol}^{-1}\right)$ were obtained from New England Nuclear. Succinate, malate, polyvinylpyrrolidone and fatty acid-free bovine serum albumin were purchased from Sigma. All other chemicals used were of the highest grade commercially available. Seeds for soybean (Glycine max var. Prize) and cowpea (Vigna unguiculata var. Queen Anne) plants were purchased from the Burpee Seed Co., Warminster, Pa, USA.

Strains and culture conditions. Two strains of slow-growing rhizobia were used in this study. Rhizobium japonicum (USDA I-110) was provided by Dr H. Keyser of the USDA and strain 3I6N10 (USDA 3278) of the cowpea rhizobia was provided by Dr G. Elkan of North Carolina State University. Both strains were grown on a minimal medium as described by Brown \& Dilworth (1975), with $\mathrm{NH}_{3}(12 \mathrm{mM})$ as the nitrogen source and $12 \mathrm{mM}$ of the appropriate carbon source (glucose, unless otherwise indicated). Cultures $(500 \mathrm{ml})$ were grown in 2-litre flasks at $30^{\circ} \mathrm{C}$ in a reciprocating shaker at approximately 5 cycles $\min ^{-1}$ for $6 \mathrm{~d}$ at $\mathrm{pH} 6.8$ (final $\mathrm{OD}_{600}^{1} \mathrm{~cm}=0.30-0.35$ ). Prior to all experiments cells were harvested at $16000 \mathrm{~g}$, washed twice in TD buffer $(50 \mathrm{~mm}$-Tris/HCl, $1 \mathrm{mM}$-DTT, $5 \mathrm{mM}-\mathrm{MgCl}_{2}, \mathrm{pH} 7.5$ ) and resuspended in approximately $5 \mathrm{ml}$ of the same buffer to give a constant cell density of $1.5 \times 10^{10}$ cells ml $^{-1}$. Stock cultures were maintained on yeast extract/mannitol or yeast extract/glucose agar slants (Keele et al., 1969).

Isolation of crude bacteroid fraction. Seeds of host plants were surface-sterilized with $0.001 \%$ mercuric chloride for $30 \mathrm{~min}$, and rinsed eight times with sterile water. They were then germinated in a sterile moisture chamber on moistened filter paper, and inoculated within $2 \mathrm{~d}$ after germination with exponentially growing cultures of the appropriate symbiont grown on soil extract-glucose broth (American Type Culture Collection, 1982). Germinated, inoculated seedlings were grown on washed, coarse sand under greenhouse conditions $\left(24^{\circ} \mathrm{C}\right.$; normal day length) and were watered with a nitrogen-free salts solution and water (Sloger, 1969). Between 40 and 60 nodules, 3-4 weeks old, were harvested into ice-cold buffer containing $50 \mathrm{~mm}$-Tris/ $\mathrm{HCl}, \mathrm{pH} 7 \cdot 5,1 \mathrm{mM}-\mathrm{DTT}, 5 \mathrm{mM}-\mathrm{MgCl}_{2}$, $0.3 \mathrm{M}$-sucrose, $4 \%(\mathrm{w} / \mathrm{v})$ soluble polyvinylpyrrolidone and $3 \%(\mathrm{w} / \mathrm{v})$ fatty acid-free bovine serum albumin (bacteroid buffer). The nodule suspension $\left(0.5 \mathrm{~g} \mathrm{ml}^{-1}\right)$ was ground in a mortar and pestle, homogenized ( 5 strokes manually in a dounce homogenizer) and filtered through four layers of cheesecloth (Ching et al., 1977). All of these steps were carried out on ice. The filtrate was centrifuged at $200 \mathrm{~g}$ for $5 \mathrm{~min}$ to remove large plant fragments. The supernatant was subjected to one centrifugation at $5000 \mathrm{~g}$ for $10 \mathrm{~min}$, and the pellet containing the bacteroid fraction was washed once and taken up in bacteroid buffer (crude bacteroid fraction).

Bacteroid purification. The crude bacteroid suspension $(1.25 \mathrm{ml})$ was layered on an $11 \mathrm{ml}$ discontinuous sucrose gradient as described by Ching et al. (1977). Bacterial, partially transformed bacterial, and mature bacteroidal fractions were separated on a sucrose gradient as described by Ching et al. (1977). The mature bacteroid fraction at the $45 \% / 50 \%$ sucrose interface was carefully removed with a Pasteur pipette (total volume $=1 \mathrm{ml}$ ), centrifuged at $17000 \mathrm{~g}$ for $10 \mathrm{~min}$, washed in bacteroid buffer, and taken up in $2 \mathrm{ml}$ of the same buffer.

Uptake assays. With cells grown in culture, uptake experiments were performed at $30^{\circ} \mathrm{C}$ in a rotary shaker in buffer ( $\mathrm{pH} 7.5$ ) containing a mixture of mineral salts: $2.4 \mathrm{mM}$-potassium phosphate, $1 \mathrm{mM}-\mathrm{NH}_{4} \mathrm{NO}_{3}, 1.3 \mathrm{mM}$ $\mathrm{NaCl}, 0.4 \mathrm{~mm}-\mathrm{MgSO}_{4}$ plus trace minerals (Brown \& Dilworth, 1975), $15 \mathrm{mM}$-Tris/HCl, 0.3 MM-DTT, $50 \mu \mathrm{l}$ cell suspension and $50 \mu \mathrm{l}$ water or inhibitor in a total volume of $0.45 \mathrm{ml}$ (final cell density $=1.7 \times 10^{9}$ cells ml-1 or $0.4 \mathrm{mg}$ protein $\left.\mathrm{ml}^{-1}\right)$. The cell suspension was in all cases incubated with this mixture for $2 \mathrm{~min}$ prior to the addition of the radioactive substrate. The desired amount (usually $50 \mathrm{nmol})$ of $\left[{ }^{14} \mathrm{C}\right]$ succinate $\left(185 \mathrm{MBq} \mathrm{mmol}^{-1}\right)$ or $\left[{ }^{14} \mathrm{C}\right]$ malate $\left(185 \mathrm{MBq} \mathrm{mmol}^{-1}\right)$ was then added in a $50 \mu \mathrm{l}$ volume and uptake was terminated at various times by filtering $50 \mu \mathrm{l}$ of the suspension through a nitrocellulose filter $(0.45 \mu \mathrm{m}$, Millipore), and washing once with 1.5 $\mathrm{ml}$ of mineral salts buffer. The filters were air-dried and radioactivity was determined in toluene/Triton X-100 $(2: 1, \mathrm{v} / \mathrm{v})$ scintillation fluid containing $\left(1^{-1}\right): 0.33 \mathrm{~g}$ PPO and $0.125 \mathrm{~g}$ dimethyl POPOP.

For bacteroid preparations, uptake experiments were performed as described above except that bacteroid buffer replaced the incubation and washing buffers. In the inhibitor studies using arsenate, phosphate was omitted from the incubation mixture.

Protein assay. Total protein was assayed by the Lowry method, with BSA as the standard. 
Osmotic shock. Cells were osmotically shocked using a procedure similar to that described by de Vries et al. (1982). Cells were washed with TD buffer, incubated in $50 \mathrm{~mm}$-Tris/ $\mathrm{HCl}, 1 \mathrm{mM}$-EDTA and $0.6 \mathrm{M}$-sucrose, $\mathrm{pH} 7.5$, for $30 \mathrm{~min}$ at $30^{\circ} \mathrm{C}$ and subjected to osmotic shock by a rapid 40 -fold dilution into distilled water at $4{ }^{\circ} \mathrm{C}$ and vortexing for $45 \mathrm{~s}$. Before uptake was assayed, the cells were centrifuged at $10000 \mathrm{~g}$ and resuspended in TD buffer.

\section{RESULTS}

\section{Dicarboxylate uptake in cultured cells}

The uptake of succinate and malate in cultured cells of both slow-growing strains was effectively inhibited by the protonophore 2,4-DNP and the electron transport inhibitor KCN (Fig. 1). This uptake was active for both compounds, since the intracellular concentrations of succinate and malate attained after $2 \mathrm{~min}$ were approximately 50-fold and 10-20-fold the medium concentration of these compounds, respectively, for both strains [assuming that $1 \mathrm{mg}$ dry wt of cells occupies a volume of approximately $5 \mu$ (Reibach \& Streeter, 1984) and that approximately $50 \%$ of the dry wt of cells is protein (G. Jacobson, unpublished observation)]. Potassium arsenate did not inhibit the uptake of either compound appreciably, suggesting that dicarboxylate uptake is not dependent on a high energy phosphate intermediate. Malate and succinate were found to inhibit the uptake of one another by about $50 \%$ when present in equimolar concentrations, implying that a common carrier could be involved (Table 1). Glucose present in the assay mixture was found to exert only a slight inhibitory effect on dicarboxylate uptake in both strains (Table 1). The rates of succinate and malate uptake in cells grown on succinate, malate, glucose or succinate plus glucose were essentially the same (Fig. 2). This suggests that dicarboxylate uptake activity in these strains is expressed constitutively.

Kinetic experiments designed to determine whether succinate and malate are taken up by the same system were done with cultured cells of strain I-110 (Fig. 3). Competitive inhibition of succinate uptake by malate (Fig. $3 a$ ) and of malate uptake by succinate (Fig. $3 b$ ) occurred, indicating a common rate-limiting step in the uptake of the two substrates. Similar results were recently obtained by McAllister \& Lepo (1983) in two other strains of $R$. japonicum.

To determine if the dicarboxylate uptake systems were dependent on free thiol groups, cultured cells were treated with NEM, which caused a marked decrease in the abilities of freeliving cells to take up dicarboxylates (Table 1). Pretreatment of cells with NEM in the presence of a 100 -fold excess of substrate followed by removal of the inhibitor did not protect against inactivation (not shown).

The potential involvement of periplasmic binding proteins in the uptake of dicarboxylic acids was investigated by observing the sensitivity of uptake to osmotic shock. The uptake of succinate and malate in cultured cells of both strains was markedly inhibited by this treatment (Fig. $4 a, b$ ). This osmotic shock procedure did not inhibit glucose uptake in these strains (unpublished), showing that this treatment did not cause general membrane or physiological damage.

\section{Dicarboxylate uptake by crude and purified bacteroid preparations}

Both crude and purified bacteroid preparations were assayed for their ability to take up succinate and malate (Fig. 5). After $5 \mathrm{~min}$, the intracellular concentrations of succinate and malate were approximately 5-11-fold and 3-4-fold the medium concentrations, respectively, of these compounds, except for malate uptake in purified bacteroids, which was not detected. Some malate uptake, however, was detected in the crude preparation. The uptake of succinate was found to be sensitive to the metabolic inhibitors KCN and 2,4-DNP in both preparations, as was the uptake of malate in crude bacteroids (Table 2). As in cultured cells, arsenate or glucose had only a slight inhibitory effect on dicarboxylate uptake in bacteroids (Table 2). Also, NEM was found to greatly decrease dicarboxylate uptake in crude bacteroids (Table 2), and pretreatment with substrate did not result in any protection against the effect of this compound, as was the case for cultured cells (not shown). In contrast to cultured cells, however, osmotic shock treatment of bacteroids using the same procedure as for free-living cells did not result in loss of succinate uptake activity (Fig. $4 c, d$ ). 


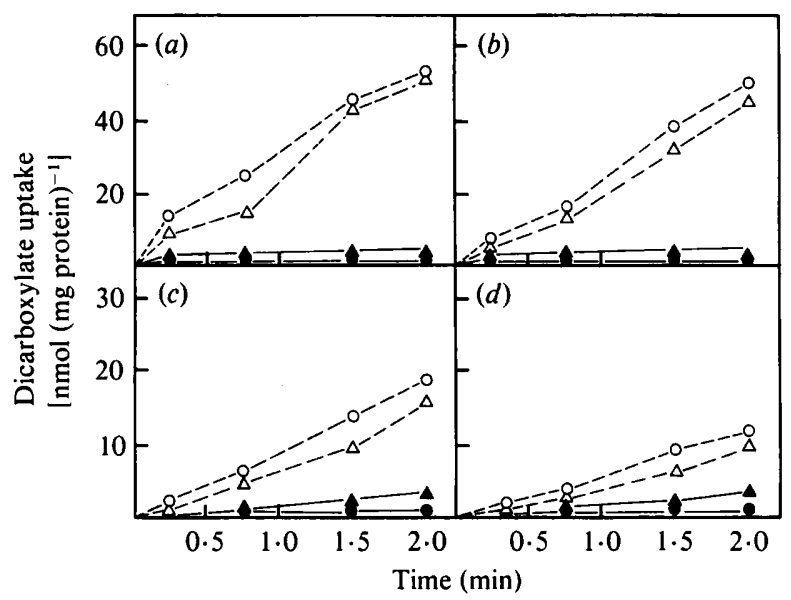

Fig. 1. Energy dependence of dicarboxylic acid uptake in cultured cells. The uptake of $0.1 \mathrm{~mm}-$ $\left[{ }^{14} \mathrm{C}\right]$ succinate and $0 \cdot 1 \mathrm{mM}-\left[{ }^{14} \mathrm{C}\right]$ malate was measured with washed cells from glucose-grown cultures. (a) $\left[{ }^{14} \mathrm{C}\right]$ Succinate uptake in strain $\mathrm{I}-110 ;(b)\left[{ }^{14} \mathrm{C}\right]$ succinate uptake in strain $3278 ;(c)\left[{ }^{14} \mathrm{C}\right]$ malate uptake in strain $\mathrm{I}-110 ;(d)\left[{ }^{14} \mathrm{C}\right]$ malate uptake in strain 3278 . O, Uptake without the addition of inhibitor; $\triangle$, uptake with $5 \mathrm{mM}$-arsenate added $2 \mathrm{~min}$ prior to the addition of radioactive substrate; $\boldsymbol{\Lambda}$, uptake with 0.8 mM-2,4-DNP added $2 \mathrm{~min}$ prior to the addition of radioactive substrate; with $5 \mathrm{mM}-\mathrm{KCN}$ added $2 \mathrm{~min}$ prior to the addition of radioactive substrate. Each point is the mean of at least three independent determinations.

\section{Table 1. Effect of inhibitors on $\left[{ }^{14} \mathrm{C}\right]$ succinate and $\left[{ }^{14} \mathrm{C}\right]$ malate uptake in cultured cells}

Uptake is expressed as percentage of control rates (no inhibitor) which were in nmol $\mathrm{min}^{-1}$ (mg protein $)^{-1}: 23$ for succinate and 12 for malate in strain $\mathrm{I}-110$, and 28 for succinate and $\mathbf{4 . 7}$ for malate in strain 3278. Uptake was terminated at $2 \mathrm{~min}$ under conditions described in Methods. Values given are the means $( \pm \mathrm{SD})$ of three independent determinations in each case.

\author{
${ }^{14}$ C-labelled \\ substrate \\ $(0 \cdot 1 \mathrm{~mm})$
}

Succinate

Malate

\begin{tabular}{lcc} 
Inhibitor (mM) & $\begin{array}{c}\text { Percentage } \\
\text { uptake in strain: }\end{array}$ \\
\cline { 2 - 3 } None & 100 & 3278 \\
Malate $(0 \cdot 1)$ & $43( \pm 3 \cdot 7)$ & 100 \\
Glucose $(0 \cdot 1)$ & $85( \pm 3 \cdot 1)$ & $86( \pm 6)$ \\
NEM $(1 \cdot 0)$ & $13( \pm 4 \cdot 8)$ & $16( \pm 2)$ \\
None & 100 & 100 \\
Succinate $(0 \cdot 1)$ & $58( \pm 4 \cdot 5)$ & $47( \pm 9)$ \\
Glucose $(0 \cdot 1)$ & $95( \pm 0 \cdot 5)$ & $80( \pm 4)$ \\
NEM $(1 \cdot 0)$ & $39( \pm 1 \cdot 7)$ & $19( \pm 7)$
\end{tabular}

Percentage

\section{Kinetic measurements of dicarboxylate uptake}

The uptake of succinate and malate was a saturable function of substrate concentration for both strains and for both cell types. Table 3 gives the kinetic constants determined by measuring the initial uptake rate of these compounds at concentrations varied between 1 and $25 \mu \mathrm{M}$. The maximal velocity of succinate uptake was 5 -fold higher, and of malate was about 20 -fold higher, in cultured cells compared to crude bacteroids of strain I-110, while in strain 3278 both compounds were accumulated at 20-25-fold higher rates in cultured cells compared to crude bacteroids. There was no significant difference between cultured and crude bacteroid cells, however, in apparent $K_{\mathrm{m}}$ values for succinate uptake, while the $K_{\mathrm{m}}$ values for malate uptake were about 3-fold higher in crude bacteroids compared to free-living cells (Table 3 ). No marked differences were observed in either the maximal rates of uptake, or in $K_{\mathrm{m}}$ values, for dicarboxylates between $R$. japonicum and cowpea Rhizobium uptake systems (Table 3). These 


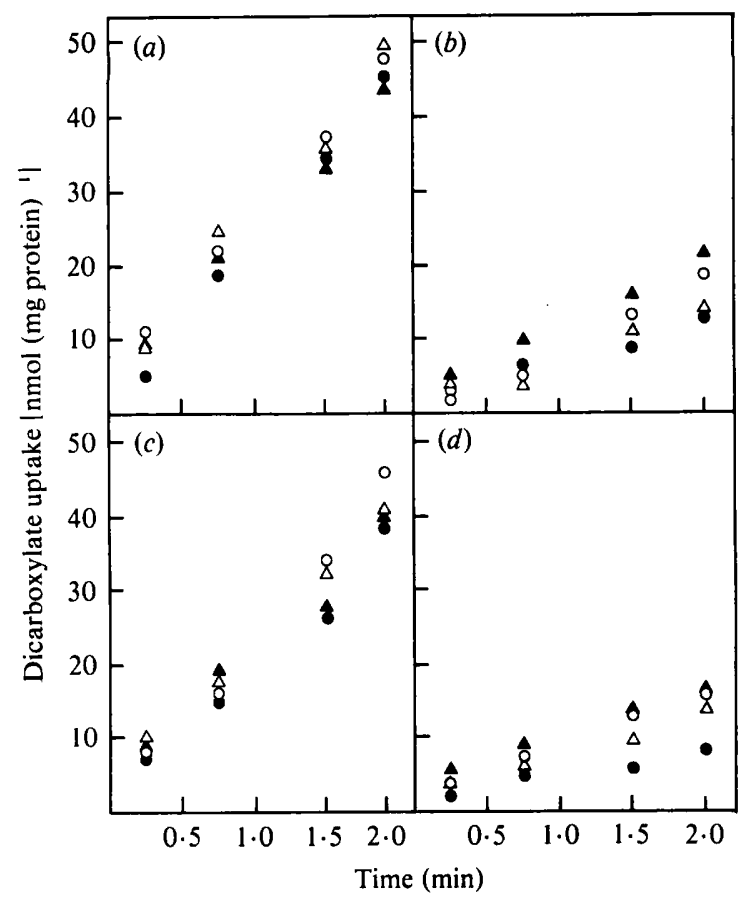

Fig 2. Dicarboxylic acid uptake by cultured cells grown on different sources of carbon. (a) $\left[{ }^{14} \mathrm{C}\right]$ Succinate uptake by strain $\mathrm{I}-110 ;(b)\left[{ }^{14} \mathrm{C}\right]$ malate uptake by strain $\mathrm{I}-110 ;(c)\left[{ }^{14} \mathrm{C}\right]$ succinate uptake by strain $3278 ;(d)\left[{ }^{14} \mathrm{C}\right]$ malate uptake by strain 3278 . $O$, glucose-grown cells; $O$, succinate-grown cells; $\Delta$, malate-grown cells: $\boldsymbol{\Delta}$, succinate plus glucose-grown cells. The initial concentration of dicarboxylic acid in the assay was $0.1 \mathrm{~mm}$. Each point is the mean of three independent determinations.

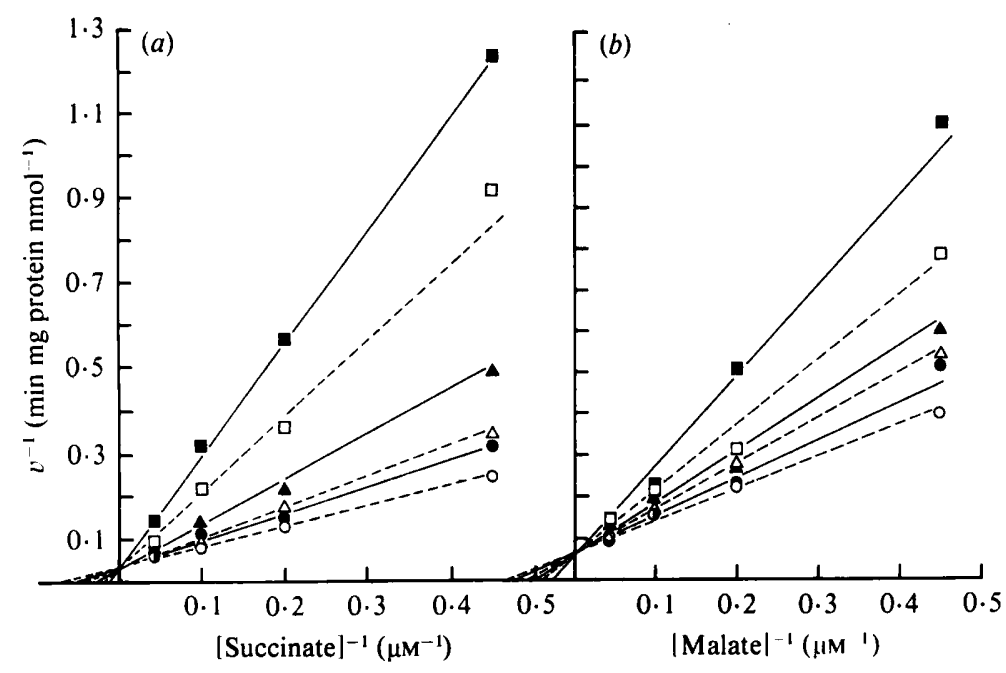

Fig. 3. Mutual inhibition of succinate and malate uptake in cultured cells of strain I-110. Inhibition of $\left[{ }^{14} \mathrm{C}\right]$ succinate $(a)$ and $\left[{ }^{14} \mathrm{C}\right]$ malate $(b)$ uptake by different concentrations of malate and succinate, respectively, was measured as a function of substrate concentration. The lines through the data points of the double reciprocal plots represent a least squares fit. $O$, No inhibitor;, $2.2 \mu \mathrm{M}$-inhibitor; $\triangle$, $5 \mu \mathrm{M}$-inhibitor; $\Delta, 22 \mu \mathrm{M}$-inhibitor; $\square, 50 \mu \mathrm{M}$-inhibitor; $\square, 100 \mu \mathrm{M}$-inhibitor. Each point is the mean of three independent determinations. $K_{\mathrm{i}}$ values obtained from these plots were $13( \pm 5) \mu \mathrm{M}$ for malate inhibition of succinate uptake and $25( \pm 5) \mu \mathrm{M}$ for succinate inhibition of malate uptake. 


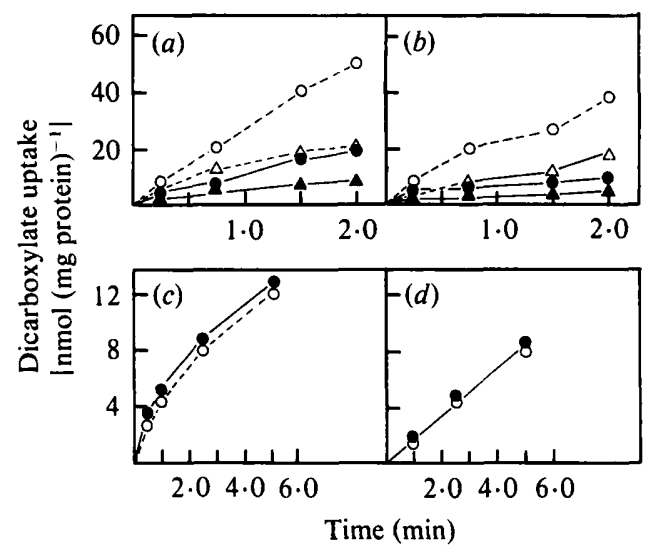

Fig. 4. Effect of osmotic shock on dicarboxylic acid uptake in cultured cells and crude bacteroids. An initial concentration of $0 \cdot 1 \mathrm{~mm}-\left[{ }^{14} \mathrm{C}\right]$ succinate or $\left[{ }^{14} \mathrm{C}\right]$ malate was used. (a) Cultured cells, strain I-110; (b) cultured cells, strain 3278 ; (c) bacteroids, strain I-110; (d) bacteroids, strain 3278 . O, Succinate uptake by untreated cells; $O$, succinate uptake by osmotically shocked cells; $\triangle$, malate uptake by untreated cells; $\boldsymbol{\Delta}$, malate uptake by osmotically shocked cells. Each point is the mean of three independent determinations.

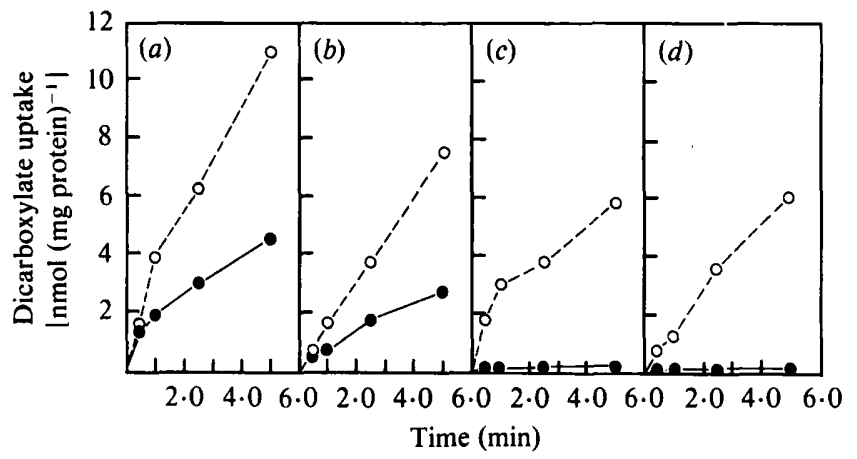

Fig. 5. Dicarboxylic acid uptake by crude and purified bacteroids. The uptake of $\left[{ }^{14} \mathrm{C}\right]$ succinate and $\left[{ }^{1+} \mathrm{C}\right]$ malate by crude bacteroids of strains I-110 $(a)$ and $3278(b)$, and purified bacteroids of strains I-110 $(c)$ and $3278(d)$ was measured in washed cell suspensions containing $0.1 \mathrm{mM}$ of either acid. $O$, Succinate uptake;, malate uptake. Each point is the mean of three independent determinations.

data also show that the maximal uptake rates in both species are greater for succinate than for malate in both cultured cells and in crude bacteroids. Kinetic parameters for malate uptake in purified bacteroids could not be determined since these cells failed to accumulate this dicarboxylic acid (Fig. 5).

\section{DISCUSSION}

The susceptibilities of the dicarboxylate uptake systems of the two species of slow-growing Rhizobium to KCN and 2,4-DNP (Fig. 1 and Tables 1 and 2) indicate that the systems are dependent upon an energized membrane state as has been shown for other rhizobia (Glenn $e t$ al., 1980; Finan et al., 1981; McAllister \& Lepo, 1983). Dicarboxylate uptake was severely inhibited by NEM as has also been found in Escherichia coli (Lo et al., 1972) and in $R$. leguminosarum (Glenn et al., 1980). Under the conditions used here for NEM modification, predominantly thiol groups are affected (Riordan \& Vallee, 1967). Thus, the inhibition of dicarboxylate uptake by NEM in cultured and symbiotic cells of both strains indicates the involvement of free thiol groups in maximal uptake activities. The inability of substrates to protect against NEM inactivation may indicate that the modified thiol groups and the substrate binding site are separate. 
Table 2. Effects of inhibitors on dicarboxylic acid uptake in bacteroids

Rates of uptake of $0.1 \mathrm{~mm}-\left[{ }^{14} \mathrm{C}\right]$ succinate and $0.1 \mathrm{~mm}-\left[{ }^{14} \mathrm{C}\right] \mathrm{malate}\left[\mathrm{nmol} \mathrm{min}{ }^{-1}(\mathrm{mg} \text { protein })^{-1}\right]$ in the absence of inhibitor were 2.2 and 0.7 , respectively, for crude I-110 bacteroids and 1.5 and 0.3 , respectively, for crude 3278 bacteroids. The rates of uptake of $0.1 \mathrm{mM}-\left[{ }^{14} \mathrm{C}\right]$ succinate in the absence of inhibitor were 0.9 and 1.2 for purified bacteroids of strains I-110 and 3278 , respectively. Values are means $( \pm S D)$ of three determinations in each case.

\begin{tabular}{|c|c|c|c|c|c|}
\hline \multirow{2}{*}{$\begin{array}{l}\text { Bacteroid } \\
\text { preparation }\end{array}$} & \multirow[b]{2}{*}{ Inhibitor (mM) } & \multicolumn{2}{|c|}{$\begin{array}{l}\text { Percentage succinate } \\
\text { uptake in strain: }\end{array}$} & \multicolumn{2}{|c|}{$\begin{array}{l}\text { Percentage malate } \\
\text { uptake in strain: }\end{array}$} \\
\hline & & $\mathrm{I}-110$ & 3278 & $\mathrm{I}-110$ & 3278 \\
\hline Crude & $\begin{array}{l}\text { None } \\
\text { KCN (5) } \\
2,4-D N P(0 \cdot 8) \\
\text { Arsenate }(5) \\
\text { Glucose }(0 \cdot 1) \\
\text { NEM }\end{array}$ & $\begin{array}{l}100 \\
<1 \\
45( \pm 3) \\
81( \pm 2) \\
95( \pm 7) \\
12( \pm 2)\end{array}$ & $\begin{array}{l}100 \\
2 \cdot 5( \pm 0 \cdot 3) \\
22( \pm 4) \\
85( \pm 2) \\
70( \pm 2) \\
22( \pm 2)\end{array}$ & $\begin{array}{l}100 \\
1 \cdot 5( \pm 0 \cdot 2) \\
49( \pm 5) \\
76( \pm 1) \\
89( \pm 4) \\
12( \pm 1)\end{array}$ & $\begin{array}{l}100 \\
1 \cdot 2( \pm 0 \cdot 3) \\
33( \pm 4) \\
70( \pm 2) \\
70( \pm 2) \\
6( \pm 2)\end{array}$ \\
\hline Purified & $\begin{array}{l}\text { None } \\
\text { KCN (5) } \\
\text { 2,4-DNP (0.8) }\end{array}$ & $\begin{array}{l}100 \\
2 \cdot 6( \pm 0 \cdot 2) \\
45( \pm 3)\end{array}$ & $\begin{array}{l}100 \\
9 \cdot 1( \pm 1 \cdot 4) \\
46( \pm 5 \cdot 6)\end{array}$ & $\begin{array}{l}\text { ND } \\
- \\
-\end{array}$ & $\begin{array}{l}\text { ND } \\
- \\
-\end{array}$ \\
\hline
\end{tabular}

ND, None detected (cf. Fig. 5).

Table 3. Kinetic measurements for $\left[{ }^{14} \mathrm{C}\right]$ succinate and $\left[{ }^{14} \mathrm{C}\right]$ malate uptake in cultured cells and crude bacteroids

\begin{abstract}
Values of $K_{\mathrm{m}}$ and $V_{\max }$ were obtained from double reciprocal plots of initial uptake rates (the means of at least three trials at each substrate concentration) at dicarboxylate concentrations that varied between 1 and $25 \mu \mathrm{M}$. The values were calculated by the statistical procedure suggested by Nimmo \& Atkins (1979). $V_{\max }$ is given in nmol $\mathrm{min}^{-1}(\mathrm{mg} \text { protein })^{-1}$. Uptake was terminated at $15 \mathrm{~s}$ for cultured cells and $30 \mathrm{~s}$ for bacteroids, which was within the linear range of uptake rate as determined in independent experiments.
\end{abstract}

Organism

I-110 Cultured cells

1-110 Bacteroids*

3278 Cultured cells

3278 Bacteroids*

$\overbrace{K_{\mathrm{m}}(\mu \mathrm{M})}^{\text {Succinate uptake }} \boldsymbol{V}_{\max }$

* Similar values were obtained for succinate uptake in purified bacteroid preparations, although purified bacteroids failed to take up malate (cf. Fig. 5).

Dicarboxylate uptake in both species appeared to be constitutive since maximal uptake activity was similar in cells grown on dicarboxylic acids and cells grown on glucose. The uptake was not found to be subject to significant repression by glucose in cells grown on both sugar and dicarboxylic acid (Fig. 2). These observations are somewhat in contrast to those of McAllister \& Lepo (1983) who reported a $63 \%$ and $92 \%$ loss in succinate uptake activity in strains 110 and 217 of $R$. japonicum, respectively, grown on glucose. Our results are not consistent with the control of dicarboxylate transport by catabolite repression or a similar mechanism in the species studied. Indeed, $\mathrm{C}_{4}$ dicarboxylic acids appear to repress glucose uptake in these species rather than the reverse (unpublished).

In cultured cells, the uptake of both succinate and malate was partially sensitive to osmotic shock (Fig. 4), suggesting a possible dependence on periplasmic binding proteins (cf. de Vries $e t$ al., 1982). The finding that dicarboxylate uptake in crude bacteroids was insensitive to the same osmotic shock procedure suggests either that these differentiated cells possess fundamentally different dicarboxylate transport systems, or that the procedure employed fails to release periplasmic proteins of bacteroids. Yet another possibility could be that periplasmic binding 
proteins are lost in bacteroid isolation. Although this may be true for malate (see below), it does not seem to be a likely explanation for succinate since the $K_{\mathrm{m}}$ values for succinate uptake in cultured cells and bacteroids are very similar and do not reflect a loss of binding proteins (Anraku, 1978).

Our kinetic data for the uptake of succinate and malate in cultured cells (Table 3 ) differ somewhat from those obtained previously by McAllister \& Lepo (1983) in other strains of slowgrowing rhizobia. For example, the $V_{\max }$ for succinate uptake in cultured cells of strain I-110 was about 15 -fold higher than the value reported by these workers. The different maximal uptake rates observed in our study may be explained in part by differences in experimental conditions. For example, uptake was measured at room temperature in the procedure of McAllister \& Lepo (1983), whereas the temperature used in this study was $30^{\circ} \mathrm{C}$.

The $V_{\max }$ values for both succinate and malate uptake were considerably lower in crude bacteroids than those for cultured cells of both strains (Table 3), but similar to the values obtained recently by Reibach \& Streeter (1984) in bacteroids of a different $R$. japonicum strain. The bacteroid preparation used by these workers was likely to comprise not only differentiated bacteroids, but also 'transforming' and untransformed bacteria since their bacteroid isolation procedure did not separate these different cell types (Reibach et al., 1981). However, when a procedure that does separate these cell types was used (Ching et al., 1977), purified mature bacteroids of both strains accumulated succinate but not malate (Fig. 5). Whether this loss of malate uptake activity is inherent in the differentiation process, or represents damage to the bacteroids during their purification (for example loss of a malatespecific binding protein from the periplasm), remains to be determined. However, this observation is especially intriguing in view of the fact that in cultured cells there must be a common rate-limiting step for the uptake of these two compounds (Fig. 3).

Our data are consistent with the hypothesis that succinate may be a preferred carbon and energy source for bacteroids of slow-growing rhizobia, as has been reported to be the case in fastgrowing species (Ronson et al., 1981; Finan et al., 1983). However, the development of a vesicular system in which to study rhizobial transport directly, uncoupled from metabolism, and perhaps the use of bacteroids isolated by procedures in which the peribacteroid membranes remain intact (Verma et al., 1978), will ultimately be necessary to assess the full transport capabilities of symbiotic rhizobial cells.

This research was supported, in part, by a grant from the Boston University Graduate School. Portions of this work formed part of the PhD thesis of M. J. D. San Francisco (Boston University, 1984) and were presented in a preliminary form at the annual meeting of the American Society for Microbiology in New Orleans, La, USA (1983).

\section{REFERENCES}

American Type Culture Collection (1982). Catalogue of Strains I, 15th edn, p. 606. Rhizobium X medium. Rockville, Md: American Type Culture Collection.

ANRAKU, Y. (1978). Active transport of amino acids. In Bacterial Transport, pp. 171-219. Edited by B. P. Rosen. New York: Marcel Dekker.

Brown, C. M. \& DilworTH, M. J. (1975). Ammonia assimilation by Rhizobium cultures and bacteroids. Journal of General Microbiology 86, 39-48.

Ching, T. M., Hedtke, S. \& Newcomb, W. (1977). Isolation of bacteria, transforming bacteria and bacteroids from soybean nodules. Plant Physiology 60, $771-774$.

Dilworth, M. J. \& GlenN, A. R. (1981). Control of carbon substrate utilization by rhizobia. In Current Perspectives in Nitrogen Fixation, pp. 244-251. Edited by A. H. Gibson \& W. E. Newton. Amsterdam: Elsevier/North Holland.

Finan, T. M., WoOd, J. M. \& JoRdan, D. C. (1981).
Succinate transport in Rhizobium leguminosarum. Journal of Bacteriology 148, 193-202.

Finan, T. M., WoOd, J. M. \& Jordan, D. C. (1983). Symbiotic properties of $\mathrm{C}_{4}$-dicarboxylic acid transport mutants of Rhizobium leguminosarum. Journal of Bacteriology 154, 1403-1413.

Gardiol, A., Arias, A., Cervanansky, C. \& MarTINEZ-DE DRETS, G. (1982). Succinate dehydrogenase mutant in Rhizobium meliloti. Journal of Bacteriology 151, 1621-1623.

Glenn, A. R., Poole, P. S. \& Hudman, J. F. (1980). Succinate uptake by free-living and bacteroid forms of Rhizobium leguminosarum. Journal of General Microbiology 119, 267-271.

JORDAN, D. C. (1982). Transfer of Rhizobium japonicum Buchanan 1980 to Bradyrhizobium gen. nov., a genus of slow-growing root nodule bacteria from leguminous plants. International Journal of Systematic Bacteriology 32, 136-139.

Keele, B. B., JR, Hamilton, P. B. \& Elkan, G. H. 
(1969). Glucose catabolism in Rhizobium japonicum. Journal of Bacteriology 97, 1184-1191.

Lo, T. C. Y., Rayman, M. K. \& Sanwal, B. D. (1972). Transport of succinate in Escherichia coli. I. Biochemical and genetic studies of transport in whole cells. Journal of Biological Chemistry 247, 63236331.

McAllister, C. F. \& Lepo, J. E. (1983). Succinate transport by free-living forms of Rhizobium japonicum. Journal of Bacteriology 153, 1155-1162.

Nimmo, I. A. \& AtKins, G. L. (1979). The statistical analysis of non-normal (real?) data. Trends in Biochemical Science 4, 236-239.

Reibach, P. H. \& Streeter, J. G. (1984). Evaluation of active versus passive uptake of metabolites by Rhizobium japonicum bacteroids. Journal of Bacteriology 159, 47-52.

Reibach, P. H., Mask, P. L. \& Streeter, J. G. (1981). A rapid one-step method for the isolation of bacteroids from root nodules of soybean plants, utilizing self-generating Percoll gradients. Canadian Journal of Microbiology 27, 491-495.

RioRDAN, J. F. \& VALlEe, B. L. (1967). Reactions with
$N$-ethylmaleimide and $p$-mercuribenzoate. Methods in Enzymology 11, 541-548.

Ronson, C. W., Lyttleton, P. \& Robertson, J. G. (1981). C $C_{+}$-dicarboxylate transport mutants of Rhizobium trifolii form ineffective nodules on Trifolium repens. Proceedings of the National Academy of Sciences of the United States of America 78, 42844288.

SloGer, C. (1969). Symbiotic effectiveness and $\mathrm{N}_{2}$ fixation in nodulated soybean. Plant Physiology 44, 1666-1668.

UCKer, D. S. \& Signer, E. R. (1978). Cataboliterepression-like phenomenon in Rhizobium meliloti. Journal of Bacteriology 136, 1197-1200.

Verma, D. P. S., Kazazian, V., Zogbi, V. \& Bal, A. K. (1978). Isolation and characterization of the membrane envelope enclosing the bacteroids in soybean root nodules. Journal of Cell Biology 78, 919936.

de Vries, G., van Brussel, A. A. N. \& QuisPel, A. (1982). Mechanism and regulation of glucose transport in Rhizobium leguminosarum. Journal of Bacteriology 149, 872-879. 